\title{
Application of Education Management and Lesson Study in Teaching Mathematics to Students of Second Grade of Public School in District 3 of Tehran
}

\author{
Masoumeh Farhoush ${ }^{1}$, Parisima Majedi ${ }^{1} \&$ Mohammadreza Behrangi ${ }^{2}$ \\ ${ }^{1}$ Curriculum Planning Major, University of Science and Research in Tehran, Iran \\ ${ }^{2}$ Kharazmi University, Iran \\ Correspondence: Masoumeh Farhoush, Curriculum Planning Major, University of Science and Research in \\ Tehran, Iran. E-mail: m-farhoush@yahoo.com
}

Received: August 14, 2016

doi:10.5539/ies.v10n2p104

\author{
Accepted: September 18, 2016 \\ Online Published: January 30, 2017 \\ URL: http://dx.doi.org/10.5539/ies.v10n2p104
}

\begin{abstract}
The present paper studies the effects of lesson study as a sample of participative researches in classroom as well as Behrangi Education Management Model in courses by aiming at exploring and allowing students to use the indexes of course concepts as an effective model in learning. The research plan is pre-test, posttest with control group type. In this research, first the characteristics of lesson study in professional development of teachers through participative research and improving students' learning have been studied, followed by discussing the ten commands or ten steps of implementing education management model in teaching curriculum as well as using modern and suitable teaching models. The subjects were selected at random from five lesson study pilot schools in district 3 and were taught and tested accordingly. The measurement tools which are used in this research included teacher-developed education progress test underwent contents validity and reliability examination and their reliability was examined by reliability method which was agreed by assessor. That is, the papers were given to a number of paper correctors for scoring. The scoring scale was 1 to 14 . The teaching was carried out in two methods of lesson study and education management for teaching mathematics to second grade boy students at public elementary schools in district 2 of Tehran and the effects were measured on three groups of students in pre-test and posttest methods. The results from analyzing research data showed the average mathematics score in education management model in pretest was 9.85 and in posttest, it was 11.26; while, the average mathematics scores in lesson study group in pre-test was 9.19 and in posttest, it was 9.04. In the control group, those scores were 9.75 in pre-test and 9.65 in posttest. The average score in mathematics lesson in education management group showed considerable increase compared to the lesson study method group. The research hypothesis of the research showed education management model led to increase in mathematics learning of students; while, lesson study did not show tangible effects on mathematics learning of students. This research can be carried out in higher school grades and in other courses in Tehran for providing more complementary studies.
\end{abstract}

Keywords: education management model, lesson study, mathematics learning

\section{Introduction}

Comprehensive and fair access to high quality education for all across their lifetime is a necessity in developing universal knowledge-based populations and is considered as one of the key tools in implementation for achieving all sustained development (The manifest of World Summit on Technology in Education, 2015).

Enrichment of education culture consists of a series of teaching-learning experiences for deepening the learning. Increase in the degree of materialization of education goal, overall growth of personality and learning the values, freshness and being active, learning and development of communication skills in individual and group life, improving mental and human capacities, emotional bonds of staff and students, and self-thinking which are seldom discussed in ordinary curriculum are the goal and focal point in enriching curriculum and education culture via educational design and planning (Hourizad, 2012).

In the comparative and international studies, the educational progress of Japanese students has always been in high level (Dovai, Louise, Soga, Matsoda, Shimizo, \& Morita, 2011). 
All teachers have some implications on the personal differences among students as an outcome of apparent beliefs of teachers on the subject of the course, learning and role of teacher. Most American teachers believe personal differences serve as an obstacle in effective learning. Idealistically, meeting students' demands means recognizing performance level of each one of the students and providing different education for different levels. Japanese teachers; on the other hand, assume personal differences as natural characteristics of a group. In their opinion, the differences found in mathematics classes serve as a source for students and teachers. Personal differences are useful in classrooms; for, they lead to a series of opinions and solutions, provide grounds for students' discussions and thought, make it possible for students to compare variety of different solutions and help them to make connections among them (Stigler \& Hebert 2001).

There has been one decade since lesson study has been introduced and improved in Iran. Educational agents evaluate it as a model for education improvement and education researchers propagate it as a model of professional education of teachers in school. Educational researchers who are comparing the Japanese model of lesson study are facing some problems. Changing the old methods of professional development of teachers and organizing schools as places for teachers' learning is not an easy task. Schools need conditions, elements and facilities which provide them with approaches, strategies and tools required in facilitating lesson study process (Stibank, Apple, Liung, Turner, Mangan, \& Mitchell, 2002).

The Japanese model of lesson study has transformed schools into learning organizations. In the last decade, the lesson study has received attention of educational researchers and agents of education and learning improvement across the world. Isoda et al (2007) attribute the history of emergence of lesson study. Expansion of John Dioei's thoughts and methods during 1920 and his national schools courses in 1940s led to more expansion of lesson study. In 1980s, Baker and Siva gradually introduced lesson study to world. Of course, expansion of lesson study approach was accelerated universally by publishing the Thames results and Stinger and Hibert's books on Education Gap (1999) and today, it is recognized as one of the methods in making changes in the process of education and learning across the world (Habibzadeh, 2013).

Lesson study is based on social constructivism theory. There are three main principles in this theory. The first principle emphasizes on the social nature of knowledge. This theory believes that knowledge is developed via social interactions and it is more a shared and social experience than a personal experience (Rock \& Wilson, 2005).

Lesson study is the participative research of teachers in school and classroom. This teachers research model benefits from the quality research, education and learning rings and tries to gather teachers in the questions designing, planning, action, active observations, feedback and re-thin and learning processes; and, encourage them to exchange views, experiences, co-action and learning from each other. This "Research in education and learning" model has large effects on professional training of teachers, improving the quality of teaching, continuation of changes for school improvement, improving students learning; and, absorbing active participation of teachers in defining the ideas, plan of action and effective administration of school for reconstructing it as a learning organization (Saki, 2010).

The experiences of different countries in implementing lesson study in mathematics and science classes show teachers, in the process of lesson study, alongside students, obtain effective interaction in classroom, learning from each other, and improving education proportion to their professional conditions, especially through improvement the students-teachers interaction (Sarkararni \& Fokaya, 2009; Saito et al., 2008; Stigler \& Hibert, 2009, quoted by Sarkararaei, 2015).

\section{Stages of Lesson Study Execution}

First stage: The first stage is to establish lesson study group. Lesson study in its initial form is mostly implemented in centralized education systems and teachers who teach a specific subject in a school grade can attend in it. Teachers are divided into small groups (Saki 2010). The groups consisting of teachers in different grades and levels create a very good opportunity to understand the quality of education and providing a concept in different grades (Louise \& Hard, 2011).

Second stage: Defining the subject: The lesson study group usually selects a topic which is a part of educational goals and is placed between the existing situation of students' learning and the situation which is desirable and anticipated by teachers. The goal of group is to study the method of coverage and desirable filling of this distance and gap.

Third stage: Study and discussing the subject; in an ideal and desirable lesson study, the topic is carefully studied through studying books, papers and researches which have been already published. 
Fourth stage: Lesson planning: Since each lesson is a small part of a larger learning scope, after specifying the goals of learning and its place in curriculum, the members start the main stage of designing by discussing on teaching that course in past and quality of teaching it desirably.

Fifth stage: Teaching the topic and observing it; in this stage, the final lesson study is tested in real situation of classroom. It means, one of the group member volunteers to perform that final plan in his/her classroom in exact way and other group members try to register and record all events and matters in the classroom by taking a detailed and precise view.

Sixth stage: Evaluation of the course and reflecting its effect; in this stage, all members of the group, not only the teacher, receive feedback from the results of objective evidences presented in session, the desirability of subject of teaching, the educational materials which are used, education method and...Usually, teacher who had taught the course is allowed to talk first and express his/her opinion on the method of course execution, students learning and other main issues of the classroom; followed by other teachers' discussion on their critical views and parts of courses which in their view was problematic.

Seventh stage: Revision in the course; the teachers revise the course by considering observations and feedbacks. Their emphasis is mostly on changing materials about which, the classroom practice provides careful evidences on the necessity of their changes.

Eighth stage: Teaching and observation of revised courses, when the revised lesson plan has been prepared; the course is then taught in a different classroom. Sometimes the same teacher performs the teaching; however, in most instances, another teacher in the group undertakes the teaching.

Ninth stage: Re-evaluation and re-thinking: In this stage, all members of the group participate in a long session. Sometimes a specialist outside school is invited to attend in this meeting. The teacher who had taught the course speaks about what the group wants and expresses his/her assessment on the success of the course and parts that need revision. The observers then review it and offer some suggestions.

Tenth stage: Sharing in results. This sharing is executed in several methods. One of these methods is to write a report. This documentation and preparing reports result in saving time. Another method of sharing is to present the results of classroom research in an exhibition and inviting teachers of other schools to visit the education final version of the lesson.

Education management model: The education management model is in fact learning management. This model has special power in absorbing basic and important points of all teaching models which have been already recognized and could also use all successful experiences of teachers for improvement. The education management model has already been able to use the conceptual indexes of today organization and management issues including knowledge management, transformational leadership, dissemination leadership, multi-intelligence, spiritual intelligence, comprehensive quality management, re-engineering, intelligent capital management, learner organization, organizational learning, chaotic models, scientific management, human relations management, systemic thought, citizenship behavior, citizenship organization behavior and based on this, other management and organization model in administrating education towards learning improvement; and found a more stronger bases for strengthening and self-confidence. In this form, the supervision course and clinical guidelines courses could be used for extracting the conceptual indexes which are used in education management model; and benefit from it as a scientific method for developing model application in teaching instructors desirably. Based on the core of teachers' instructor in workshop group, and based on the principles taken from supervision and clinical guides, it will be possible to create a beautiful scene of dialogue among teachers for growth and development of teacher's profession. In this session, teachers introduce a number of their successful and recognized teaching methods, become familiar with the education management model and use them in transforming their education (Behrangi, 2015).

Emergence of a new model of education management is for ensuring the improvement of learning quality and the educational effects on students' behavior for the realization of dreams that pursue children education. This confidence has been developed as a result of participation of many students, teachers and university scholars in implementing this model in different issues of different courses, grades and educational levels. The significant effects of this model has already expanded to and shown in the statistical calculations of many semi-experimental researches and reasonable academic events. Therefore, using it finds priority for transformation in current education plans. The main core of this model consists of a number of stages; and each stage includes significant and fundamental points resulted from attention paid to education by experts in various disciplines. These stages are explained in ten stages or steps for a joint application by teachers. These stages with brief explanations of conceptual indexes are as follows: 
First step: To assign practical assignments to students for preparing a pre-organization in form of diagrams and scaffold in linking the main titles and topics of education courses. This scaffold indicates the knowledge structure of that course subject. The students themselves, rather than teacher, develop this knowledge scaffold of course subjects; therefore, the aspects of this pre-organization difference and distinguish by Devin Azwill's view. In Azwill model, teacher presents a pre-organizer in initiating the lecture in a general term. The student, by enters the classroom by having the scaffold of link among main subjects and a general image of the entire course subject with preparation for participating in activities and the process flow of information. Student, in this term, becomes familiar with that course proportion to the complexity of the course or the complexity of his own concept. Expressing pre-organization by instructor in a general term in the beginning of the course is one of the basic points of significant learning in Azwill's definition of pre-organizer. If this general statement causes the emergence of general view of the students on course subject, he can establish link between the subject he already knows and the new subjects of course topic; and a significant learning is created afterward. In education management model, preparation of organizational diagram is labeled for linking among sections, chapters, conceptual indexes and details. The sub-chapters in the text course made by the student, specifies the pre-organizer concept.

Second step: Education management focuses on students' participation, the students' participation is the important conceptual indexes of education management during its stages. In the beginning, the teacher distributes equal number of texts pages among students for extracting conceptual indexes. The teacher determines a fixed amount of course per two students. The students study and prepare the main indexes of course concepts. Each student compares his extracted indexes with the extracted indexes of another student to find confidence on the accuracy of his findings. To do that contrastive analysis, each student shall have equal number of certain pages to study. The number of members of the study groups is determined based on the number of mentioned pages in each topic and its sub-topic by observing the two persons for one similar assignment rule. In this term, there is a significant difference between this method of forming participative learning groups in ordinary methods. In the ordinary participation procedure of learning, students are divided into three to five member teams as per the number of classrooms. In some cases too, students are divided into advanced and not advanced as per the degree of their education progress; and an equal number is placed in each group. Among the disadvantages of this participative method is elimination of labeling students with being underachieved and lazy students and saving them from the burden of its impacts for their whole lives. According to education or learning management model, in determining the number of students in groups, attention is paid to topics and sub-topics, course subjects and number of pages under coverage. For example, if the number of pages which are covered in three course topics is 3, 4 and 5; respectively, and there are 24 students; first, a just and equal assignment per student is to study 2 pages. In second, it is necessary to appoint two groups of five students to study 10 pages (5 x $2=10$ ). Two four-member groups are assigned with 8 pages and two 3-member groups are assigned with 6 pages. Observing the twice number of assignment pages per student is one of the necessities in executing the model for two-person discussion and achieving precision and deep insight in subjects.

Third step: In implementing learning management model or education management models, the method of cooperation and participation of students inside and between groups serves as the core. In second step, the class was divided into two-member groups with each taking twice its share. Now, in this step, each one of the students in the two-person group has two duties; first, to express the scaffold of subjects links and also his conceptual indexes to the others; and taking his feedback as a scientific consultant; and second, to give feedback in expressing conceptual indexes of his pages. It can be ordered to outline the basic points taken from assignments on conceptual indexes cards on pieces of paper with one eighth of A4 with Lotus 16 B (in Persian Alphabet Times New Roman in English). In this step, first the groups extract the conceptual indexes via an approach as per the number of pages specified to it. Then, it compares the conceptual indexes in his assignment with the same indexes of other team to find confidence on their accuracy and reach a consensus. This arrangement helps both the teacher and the entire classroom; for, with this method, the indexes are studied with no need to direct intervention of teacher. It is better to use Jigsaw participative model, an invention of Arvin Sharon to serve as one of the participative models. This model is used more than other participative teaching models in the empirical researches on the effects of learning management model. In this step, an arrangement is adopted for the intra-group participation to discuss on the subjects of pages, the topics and sub-topics in order to make students aware of conceptual indexes and basic concepts of the course. The outcome of this step is to provide students with practicing and crating the habit of unity in multiplication. In this step, the scaffolds of the links between the topics and key points are consulted and they achieve proper information on the course subject.

Fourth step: The fourth step is inter-group participation. To become familiar with other concept indexes on the 
topics subject of focus of other groups, each groups member goes to other groups to teach his subject according to Jigsaw participative model, and after learning and teaching the conceptual indexes of the topics and subtopics of his subjects and learning basic points of subjects of other groups, he will return to its initial group; and teaches his learning to others.

Fifth step: In this step, students' domination over the insight or general image of the course subject is being focused. The teacher asks the students to be placed in examination conditions, draw the diagram of link between main subjects and mention the conceptual and basic indexes of each one of the topics and subtopics. In this step, the full work receives A score and other students take B scores to benefit from each other's help in solving their problems. In the meantime, each student who objects his score can inform the instructor through A score students and take the feedback.

Sixth step: Participation in developing a desirable curriculum. The teacher and students, based on the topics of the course, spend some time on thinking and finding personal subjects and experiences that relate to the course. They become encouraged to bring their experiences, the conceptual indexes taken from the related opinions from sites, internet and other sources. The instructors introduce a list of resources and viewpoints relevant to the course subject.

Seventh step: Determining the environmental style and learning spaces with teaching models and suitable education technology, and using the experiences and enthusiasm (learning style) of students and instructors. The education management model emphasizes on using the new hybrid concept (direction new concept) in teaching students. The term hybrid specifically is a contemporary and update term for introducing the necessity of transforming education universally with respect to information and communication technology era. This term attributes to directional duality of educational activities to use teaching model and suitable technology in official curriculum contents. The students, based on a certain direction refer to different resources relevant to course subject and find the conceptual indexes of their courses. They then use cards in other colors to distinguish their new indexes and bring those cards to their class room.

Eighth step: This step discusses students' participation in the preparation and development of scaffold for favorable and fresh links between the topics and subtopics with respect to the conceptual indexes in current context as well as points taken from new sources relevant to their course subjects. The quotation or teaching scenario and/or lesson plan in this step is designed by the direction and cooperation of instructor and participation of students and attention to the new points obtained by studying other resources. Then, the joint activities of the students and teacher is spent on determining the role, scheduling for the activities related to teaching elements, determining suitable educational models and technology as well as the method of evaluation of the results and effects of education on students' attitudes and behavior. Observing the coordination between students' learning styles, contents writing style, teacher's education style and suitable style of learning environment are among the duties of education managers' profession.

Ninth step: Participation of students and instructor in implementing new curriculum and receiving corrective feedback in the effects of education, attitudes and views. In this step, all previous steps are reviewed and executed in teaching a course subject. In this step, application of various teaching model is highly important by considering provision of new data both for the process and in terms of the development of educational effects and receiving the concepts.

Tenth step: This step is complementary evaluation. Students and teachers are enthusiastic in finding the educational effects taken from the education and for this purpose, they use two tools; one for measuring the educational progress, which is developed by teacher in each course; and second, the recently standardized measure. This measure is prepared based on the conceptual indexes of the effects of family, information process models, participative learning models, individual personality learning models and behavioral learning models. This questionnaire measures the educational effects of each step of education management model in practice. This measure in terms of validity and creditability has been developed and standardized by receiving the views of 150 students who participated in applying the model in teaching (Behrangi, 2015).

\section{Methodology}

The present research is an empirical plan of pre-test, post-test type with control group. In this research, the statistical population includes all boy students in second grade of elementary school in the elementary schools for boys in district 3 of Education Department of Tehran in school year 20-13-2014. Of this population, 72 students were selected at random from 5 pilot schools for lesson study in district 2 of Tehran. The students underwent education and test. The measurement tools in this research included the teacher developed education progress test, which was tested for its contextual validity and its reliability was proved by using the assessors' 
agreement reliability method; that is, the sheets were given to a number of correctors to score and the scoring scale ranged between 1 and 14. The effects were measured in pre-test and post-test method on three groups of students. The pre-test was first performed in all three classrooms; then, class A executed the lesson study, class B executed education management model and class $\mathrm{C}$ in another school received mathematics teaching in summation, subtraction with transport [of numbers] to prevent the effects of the two trial classrooms. One week after education, class A and B took post-test. The data was analyzed by using covariance analysis and independent $t$ test.

\section{Findings}

In this section, the table of descriptive indexes of sample individuals is presented based on mathematics score separately in pre-test and post-test along with the relevant diagram.

Table 1. The descriptive indexes of mathematics scores in pre and post test

\begin{tabular}{llcccccc}
\hline & & Number & Average & Criteria deviation & Skewness & Minimum & maximum \\
\hline \multirow{2}{*}{ Education management model group } & Pre-test & 22 & 9.85 & 2.29 & -1.86 & 2 & 14 \\
& Post-test & 22 & 11.26 & 2.14 & -1.21 & 5 & 14 \\
\multirow{2}{*}{ Lesson study group } & Pre-test & 23 & 9.19 & 2.58 & -0.65 & 2.5 & 12.75 \\
\multirow{3}{*}{ Control group } & Post-test & 23 & 9.04 & 4.56 & -0.85 & 1 & 14 \\
& Pre-test & 27 & 5.79 & 3.39 & 0.91 & 1 & 14 \\
& Post-test & 27 & 5.69 & 3.11 & 0.73 & 1.5 & 13.5 \\
\hline
\end{tabular}

As it can be seen in Table 1, the average mathematics score of education management model in pre-test is 9.85 and in posttest, it is 11.26; while, the average mathematics score of lesson study group in pre-test is 9.19 and 9.04 in post-test; and in control group, the score is 5.79 and in post score, it is 5.69.

The average score of mathematics in education management model had considerable increase, while the average mathematics score did not show tangible changes in lesson study and control groups.

Hypothesis analysis and study

The research plan is pre-test and post-test with control group. In this section, the research hypothesis was tested by using single variable covariance analysis statistical method (ANCOVA) and the results were interpreted as well. The results obtained from first hypothesis; that is, education management model is effective in mathematics learning of students; the results of which are reflected in tables 2 to 6 .

Table 2. Kolmogorov-Smirnov Test

\begin{tabular}{lcc}
\hline Scale & $\mathrm{Z}$ & Significance level-Sig \\
\hline Learning mathematics & 0.95 & 0.32 \\
\hline
\end{tabular}

Specification Z Kolmogorov-Smirnov test on normality of distribution shows the scores distribution does not differ from natural distribution $(\mathrm{P}>-0.05)$.

Table 3. The regression line slope consistency test

\begin{tabular}{lccccc}
\hline & Sum of squares (SS) & Degree of freedom (df) & Mean squares (MS) & F & Significance level \\
\hline Constanta value & 70.187 & 1 & 70.187 & 32.047 & 0.001 \\
Group & 54.291 & 1 & 54.291 & 24.789 & 0.001 \\
Pre-test & 117.458 & 1 & 117.458 & 53.631 & 0.001 \\
Groups interaction and pre-test & 26.888 & 1 & 26.888 & 12.277 & 0.001 \\
Error & 98.554 & 45 & 3.19 & & \\
Total & 4013.5 & 49 & & & \\
\hline
\end{tabular}

With respect to Table 3, the interaction between trial conditions and its variable is significant; that is, the slop of regression line for both trial conditions is not the same $(\mathrm{F}=12 / 277, \mathrm{P}<-0.5)$ 
Table 4. Lovin F test (consistency of error variances

\begin{tabular}{cccc}
\hline F & D11 & D12 & Sig \\
\hline 15.95 & 1 & 47 & 0.001 \\
\hline
\end{tabular}

By considering Table 4, the error variances in different trial conditions are not the same $(\mathrm{P}<0.05)$.

Table 5. Modified means

\begin{tabular}{lcccc}
\hline \multirow{2}{*}{ Group } & \multirow{2}{*}{ Mean } & \multirow{2}{*}{ Standard deviation } & \multicolumn{2}{c}{ Confidence distance 0.95 } \\
\cline { 4 - 5 } & & & Upper limit & Lower limit \\
\hline Test & 9.61 & 0.39 & 8.81 & 10.41 \\
Control & 7.03 & 0.35 & 6.33 & 7.74 \\
\hline
\end{tabular}

The post-test means in Table 5 is modified for the effects of covariate variables; that is, the covariate variables are not eliminated from this data effectively.

Table 6. The regression line slope consistency test

\begin{tabular}{lccccc}
\hline & Sum of squares (SS) & Degree of freedom (df) & Mean squares (MS) & F & Significance level \\
\hline Constanta value & 43.317 & 1 & 15.885 & 0.001 & 0.25 \\
Pre-test & 222.534 & 1 & 81.604 & 0.001 & 0.64 \\
Groups (main effects) & 54.228 & 1 & 19.885 & 0.001 & 0.30 \\
Error & 125.442 & 46 & & & \\
Total & 4013.50 & 49 & & & \\
\hline
\end{tabular}

As it is observed in Table 6, the one-way ANCOVA showed that by eliminating the effects of pre-test mathematics scores as coverage variable, the main effect of independent variable on the post-test mathematics scores is significant $\mathrm{P}>0.05$, Partial $\left.\mathrm{n}^{2}=0.30\right),(\mathrm{F}=19.885)$; therefore, the research hypothesis is accepted. This means, the education management model is effective in mathematics learning of students. The results obtained from the second hypothesis; that is, lesson study has effect on mathematics learning of students is shown in Tables 7 to 11 .

Table 7. Kolmogorov-Smirnov test

\begin{tabular}{lcc}
\hline Scale & $\mathrm{Z}$ & Significance level- Sig \\
\hline Learning mathematics & 0.79 & 0.54 \\
\hline
\end{tabular}

Specification Z Kolmogorov-Smirnov test on normality of distribution shows the scores distribution does not differ from natural distribution $(\mathrm{P}>-0.05)$.

Table 8 . The regression line slope consistency test

\begin{tabular}{lccccc}
\hline & Sum of squares (SS) & Degree of freedom (df) & Mean squares (MS) & F & Significance level \\
\hline Constanta value & 151.007 & 1 & 151.007 & 14.795 & 0.001 \\
Group & 123.069 & 1 & 123.069 & 12.057 & 0.001 \\
Pre-test & 57.359 & 1 & 57.359 & 5.620 & 0.022 \\
Groups interaction and pre-test & 103.141 & 1 & 103.141 & 10.105 & 0.003 \\
Error & 469.519 & 46 & 10.207 & & \\
Total & 3467.063 & 50 & & & \\
\hline
\end{tabular}

With respect to Table 8 , the interaction between trial conditions and its variable is significant; that is, the slop of regression line for both trial conditions is not the same $(\mathrm{F}=10.105, \mathrm{P}<-0.5)$. 
Table 9. Lovin F test (consistency of error variances

\begin{tabular}{cccc}
\hline F & D11 & D12 & Sig \\
\hline 28.122 & 1 & 48 & 0.001 \\
\hline
\end{tabular}

By considering Table 9, the error variances in different trial conditions are not the same $(\mathrm{P}<0.05)$.

Table 10. Modified means

\begin{tabular}{lcccc}
\hline \multirow{2}{*}{ Group } & \multirow{2}{*}{ Mean } & \multirow{2}{*}{ Standard deviation } & \multicolumn{2}{c}{ Confidence distance 0.95 } \\
\cline { 4 - 5 } & & & Upper limit & Lower limit \\
\hline Test & 8.02 & 0.78 & 6.43 & 9.61 \\
Control & 6.56 & 0.72 & 5.11 & 8.01 \\
\hline
\end{tabular}

The post-test means in Table 10 is modified for the effects of covariate variables; that is, the covariate variables are eliminated from this data effectively.

Table 11. The results of covariance analysis tests of mathematics score

\begin{tabular}{lccccc}
\hline & Sum of squares (SS) & Degree of freedom (df) & Mean squares (MS) & F & Significance level \\
\hline Constanta value & 70.456 & 1 & 70.456 & 5.783 & 0.020 \\
Pre-test & 137.838 & 1 & 137.838 & 11.313 & 0.002 \\
Groups (main effects) & 20.069 & 1 & 20.069 & 1.647 & 0.206 \\
Error & 572.66 & 47 & 12.18 & & \\
Total & 3467.063 & 50 & & & \\
\hline
\end{tabular}

As it is observed in Table 11, the one-way ANCOVA showed that by eliminating the effects of pre-test mathematics scores as coverage variable, the main effect of independent variable on the post-test mathematics scores is significant $\mathrm{P}>0.05, \mathrm{~F}=1.647$ ); therefore, the research hypothesis is rejected. This means, the lesson study does not have effects on mathematics learning of students.

After calculation of differences in pre-test and post-test scores performed on the differential scores in $t$ test of independent group. On the first hypothesis; that is, the education management model is effective on students' mathematics learning. The results of test of independent groups are reflected in Table 12.

Table 12. Independent $t$ test for comparing the mean of mathematics scores in test group (education management model) and control group

\begin{tabular}{|c|c|c|c|c|c|c|c|c|}
\hline Scales & Group & Number & Mean & $\begin{array}{l}\text { Criteria } \\
\text { deviation }\end{array}$ & $\begin{array}{l}\text { Mean criteria } \\
\text { error }\end{array}$ & $\mathrm{T}$ & $\begin{array}{c}\text { Degree of } \\
\text { freedom }(\mathrm{df})\end{array}$ & $\begin{array}{c}\text { Significance } \\
(\text { sig })\end{array}$ \\
\hline \multirow[t]{2}{*}{ Mathematics } & $\begin{array}{l}\text { Education management } \\
\text { model }\end{array}$ & 22 & 1.40 & 2.55 & 0.54 & 2.90 & 47 & 0.01 \\
\hline & Control & 27 & 0.10 & 0.79 & 0.15 & & & \\
\hline
\end{tabular}

Lovin test showed the variances consistency condition is not established $(\mathrm{F}=19.25, \mathrm{P}<0.05)$; since the variances of both groups were unequal significantly, the unequal $t$ test variances were used. As it can be observed in table 1 , by considering the significance level $(\mathrm{P}<0.05)$, the test is significant. Therefore, the research hypothesis is accepted. That is, there is a significant difference between the mean score in mathematics in test group (education management model) and control group.

On the second hypothesis; that is, lesson study is effective on mathematics learning of students, the results of $t$ tests of independent groups are reflected in Table 13. 
Table 13. Independent $t$ test for comparing the mean of mathematics scores in test group (lesson study) and control group

\begin{tabular}{lccccccc}
\hline Scales & Group & Number & Mean & $\begin{array}{c}\text { Criteria } \\
\text { deviation }\end{array}$ & $\begin{array}{c}\text { Mean criteria } \\
\text { error }\end{array}$ & $\begin{array}{c}\text { Tegree of freedom } \\
(\mathrm{df})\end{array}$ & $\begin{array}{c}\text { Significance } \\
(\text { sig) }\end{array}$ \\
\hline \multirow{2}{*}{ Mathematics } & $\begin{array}{c}\text { Lesson } \\
\text { study }\end{array}$ & 23 & 1.15 & 5.41 & 1.12 & 0.04 & 48 \\
& Control & 27 & 0.10 & 0.79 & 0.15 & \\
\hline
\end{tabular}

Lovin test showed the variances consistency condition is not established $(\mathrm{F}=33.47, \mathrm{P}<0.05)$; since the variances of both groups were unequal significantly, the unequal $t$ test variances were used. As it can be observed in Table 2 , by considering the significance level $(\mathrm{P}<0.05)$, the test is not significant. Therefore, the research hypothesis is rejected That is, there is no significant difference between the mean score in mathematics in test group (lesson study model) and control group.

\section{Discussion}

The present research has been performed by aiming on the effects of lesson study based on Japanese model and education management model in a way which is discussed in Behrangi Theory of 2014 on mathematics learning. The results of present research showed the mean in mathematics score of education management model group in pre-test is 85.9 and in post-test, it is 26.11; while the mean mathematics score in lesson study in pre-test was 19.9 and in post-test, it was 0.4 .9 ; in the control group, the pre-test score was 79.5 and the post-test score was 69.5. The results show the mean of mathematics score in education management model group had a considerable increase while the mean mathematics score in lesson study and control group did not show tangible difference.

Other results of this research showed the education management model caused an increase in students' mathematics learning, while in the Japanese lesson study model, it did not show significant effect on students' mathematics learning. In addition, the results of findings, in comparison with the mean score of the education management model group and the lesson study model with control group showed education management model led to increase in learning mathematics by students, while, the lesson study model did not show this increase in learning in comparison with control group.

The findings of this research is not in line with the findings of Sarkararani and Fukaya (2009), Sayto et al. (2008), and Stigler and Hibert (2009) on the effects of lesson study on increasing mathematics learning and sciences; however, it is in agreement with the findings of Behrangi (2015) in the approach of practicing use of key and propagating points of education such as autonomous learning, self-awareness, insight, critical thought, reasonable thought, scientific judgment, growing habit to searching and problem solving; and high level of learning.

This model is a ground for using all models of teaching for all types of students in terms of different aptitude in a classroom. In the development and application generalizing learning management, more than anything, collaboration and anticipation of instructors and experts in education. It is recommended to arrange first to have ten percent of reading enthusiast teachers to appear in education management model education class to empower themselves and direct 80 percent of teachers to accept changes towards quality transformation if they are in close reach.

By learning management model, increasing instructors' recognition of principles, theories and results of educational researches and destroying the closed walls of mental space will become possible; so in this mental capacitating and words, teachers can reach a vast, deep and flexible insight. Efforts in selecting teaching job and education management as the most honorable road in life and philosophy of life will take form in the process of empowerment in applying learning management in the direction of education goals (Behrangi 2015).

This research could be performed in other districts of Tehran, higher grades and other courses for complementary purposes. Another suggestion of the researchers of this study is to use education management model for courses with exploration goals and students' use of conceptual indexes for improving learning in lesson study and approach an Iranian model.

\section{References}

Behrangi, M. (2015). Preface of Translator on Models of Teaching-translated book-2015. Tehran, Kamal Tarbiat Publication.

Habibzadeh, A. (2013). Practical Guideline of Lesson study. Qom, Qom University Publication. 
Hourizad, B. (2012). Lesson Study, Participative Research of School Staff. Tehran, Sayeh Sokhan Publication

Manifest of Global Summit of Technology in Education. (2015). UNESCO, Drawing up the Policies of Global Future for Technology in Education, Chindaeo, Chin, June 2015.

Saki, R. (2013). Lesson Study, Fundamentals, Principles and Procedures. Tehran, ACCER Publication.

Sarkararani, M. (2015). Lesson Study, an Idea for Globalization of Education and Enrichment of Learning. Tehran, Merat Educational Innovation Center.

Stigler, J., \& Hibert, J. (2009). Educational Gap, the Best Ideas of Teachers of the World for Improving Education in Classroom (Translated by Sarkararani, Mohammadreza and Moghaddam, Alireza). Tehran, Madreseh Publication.

Stipank, J. et al. (2010). Lesson study, a Practical Guideline for Principles and Teachers (Translated by Reza Saki, Daryoush, Madani). Tehran, Hekmat Alavi Publication.

\section{Copyrights}

Copyright for this article is retained by the author(s), with first publication rights granted to the journal.

This is an open-access article distributed under the terms and conditions of the Creative Commons Attribution license (http://creativecommons.org/licenses/by/4.0/). 